\title{
The Federal Reserve Responds to Crises: September 11th Was Not the First
}

\author{
Christopher J. Neely
}

T

he terrorist attacks of September 11, 2001, had two immediate consequences: They took an enormous human toll and they created a potentially serious crisis for the economy through their impact on financial markets. The Federal Reserve reacted to the potential economic crisis by providing an unusual amount of liquidity and reducing the federal funds rate more than would be expected from levels of output and inflation. This was not the first time, however, that the Federal Reserve responded quickly and forcefully to unusual conditions in financial markets that threatened to spill over to the real economy. Indeed, the September 11 th attacks reminded us that problems in financial markets can disrupt the whole economic system.

This article describes the Federal Reserve's reactions to crises, or potential crises, in financial markets. The crises considered are periods of sudden revision in expectations or physical disruption that threaten the stability of the economic system through asset price volatility. The Federal Reserve has responded to financial crises in three main ways: (i) The Fed has provided immediate liquidity through open market operations, discount window lending, and regulatory forbearance; (ii) the Fed has lowered the federal funds target over the medium term; (iii) the Fed has participated in foreign exchange intervention with the U.S. Treasury.

The next section of the article explains how sudden changes in asset prices or asset price uncertainty spill over into the rest of the economy. Next, the article explains how the Federal Reserve Bank can use its tools to help minimize the impact of the uncertainty and physical disruptions of crises. Finally, several recent episodes-the stock market crash of 1987, the Russian default, and the September 11th attacks - are examined as case studies.

\section{HOW DO CRISES AFFECT THE ECONOMY?}

Stock market crashes, in general, the Russian default, and the September 11 th attacks were associated with sudden, substantial revisions in expectations about future economic and financial variables. Although each episode had unique causes and features, they were all accompanied by liquidity crises in financial markets that could have disrupted economic activity and threatened price stability. ${ }^{1}$ These financial crises are caused by some combination of a simple physical disruption of the financial system and/or sudden uncertainty about economic conditions. Those problems manifest themselves in lower asset prices, which, in turn, create balance sheet problems for financial institutions. ${ }^{2}$

Financial institutions are wedded together in a complex system of payments that makes the system vulnerable to the failure of large banks or hedge funds. ${ }^{3}$ And some parts of the system, like specialists on Wall Street and hedge funds, are highly leveraged, meaning that they typically borrow most of the money with which they purchase assets. ${ }^{4}$ If asset

\footnotetext{
1 Although the Federal Reserve can achieve price stability over the long run, financial crises that generate extreme economic conditions might create pressures to follow other policies. For example, a banking collapse could potentially create deflation and a liquidity trap that might require the Fed to commit to inflate the currency for some years.

2 Mishkin (2001) discusses financial crises in the context of foreign exchange crises in emerging markets.

3 Hedge funds pool investors' money to invest in a variety of financial instruments. By limiting participation to wealthy investors and large institutions, they avoid most regulatory controls and do not register with the Securities and Exchange Commission.

4 A specialist is a firm charged with making a market-being prepared to buy or sell a stock on their own account at a reasonable spread-when there is temporary excess supply or demand for a stock. Larger imbalances between supply and demand at a given price might require the specialist to halt trading temporarily, until a new opening price can be established. Ordinarily, specialists make money from the spread that compensates them for the service of providing liquidity to the market all the time. In 1987 there were about 50 specialist firms (Santoni, 1988).
} research assistance. 


\section{Figure 1}

\section{Real Gross Private Domestic Investment During Recessions}

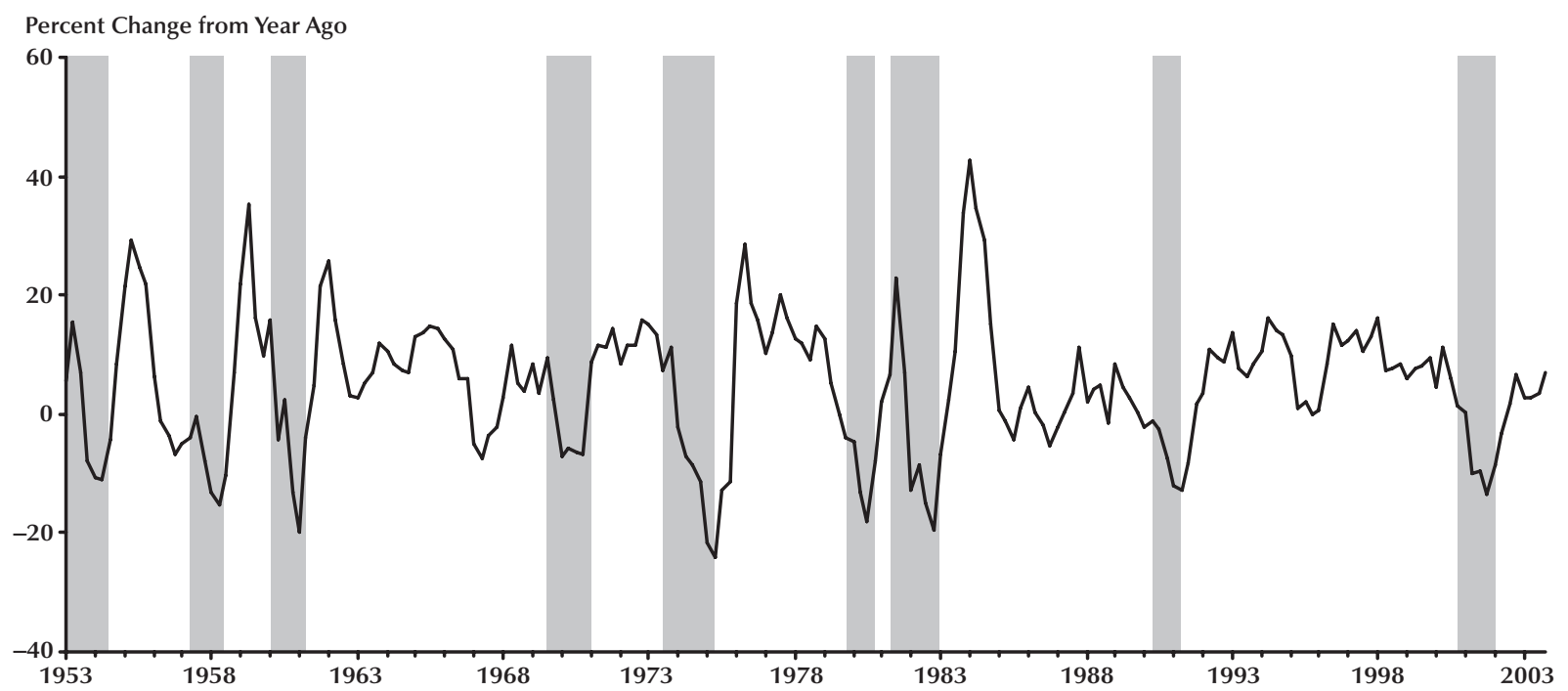

NOTE: The figure shows the year-to-year percentage change in real gross private domestic investment in the United States. Shaded bars denote recessions.

SOURCE: Bureau of Economic Analysis.

prices decline significantly, the value of the firm's liabilities (i.e., loans) can exceed the value of its assets, in which case the value of the firm to its owners (equity) becomes negative and the firm goes bankrupt without additional capital. But if a hedge fund goes bankrupt, it will be unable to make payments to the banks from which it has borrowed money, which might make them insolvent as well. Or, firms might find it necessary to ration scarce liquidity to make only particularly important payments during periods of illiquidity. In this event, some debts will not be settled on time. The danger that one's counterparty will fail to settle a transaction is called counterparty risk. Fear of counterparty risk can cause financial gridlock, where firms and individuals refuse to enter into financial transactions. Failure of counterparties to make payments can also lead to systemic risk - where the health of the whole financial system is endangered by the possibility of domino-style bankruptcy.

A breakdown of the financial system itself will immediately affect the whole economy because economic activity depends on the efficient functioning of the payments system. If one cannot be assured that one will be paid, then there is little incentive to work or to sell.

In the medium term, such financial breakdowns can hobble the economy because the financial system provides intermediation; that is, it matches people who wish to save money with firms who want to invest that money in productive activities. Other industries can have disruptions or slowdowns with little effect on other business. If the financial system stops functioning, however, savers aren't matched with investors and investment falls in every sector. And investment is traditionally the most volatile component of output. Figure 1 shows that U.S. recessions (shaded bars in the figure) are always accompanied by a large falloff in investment.

A fall in stock prices can also affect the real economy through its influence on the credit-worthiness of firms. When a firm's stock price falls, the value of the firm to its owners declines. The owners-who have limited liability - then have an incentive to borrow money to take risky but potentially profitable actions; as owners they keep any gains but their losses are limited to their equity stake. Naturally, though, no one would want to lend money to firms with low equity because this incentive to take risky gambles makes the loan too risky (Bernanke and Gertler, 1989; Calomiris and Hubbard, 1990).

Falls in equity can also affect economic activity through trade credit. Trade credit is the practice in which buyers take delivery of goods and pay for 
them later. A firm with low equity might be unable to get trade credit to continue operations. ${ }^{5}$

Financial crises in the United States that exacerbated 19th century recessions contributed fundamentally to the formation of the Federal Reserve System in 1914 (Dwyer and Gilbert, 1989). ${ }^{6}$ Prior to the creation of the Federal Reserve System, the U.S. economy was beset by occasional banking panics, particularly the severe 1907 banking panic, which directly motivated the creation of the Federal Reserve System in 1914 (Federal Reserve Bank of Minneapolis, 1988).

One of the most important responsibilities for the new central bank was to provide an elastic supply of currency to banks to meet temporary increases in currency demand. One of the most prominent sources of such temporary increases in currency demand was banking panics. In other words, a primary goal of the Federal Reserve System was to avert banking panics. Deposit insurance, prudent regulation, and the Fed's own willingness to act as a lender of last resort have made banking panics almost unheard of since the Great Depression. ${ }^{7}$ Extreme conditions, such as the terrorist attacks of September 11, 2001, can still threaten the health of the economy through their effect on financial markets. During such circumstances the Fed has continued to act as a lender of last resort to the financial system to maintain stable business conditions.

\section{HOW DOES THE FEDERAL RESERVE REACT TO FINANCIAL CRISES?}

One might think that if drastic changes in asset prices can harm the economy, then the Federal Reserve should try to prevent such changes. This conclusion is not correct. It is important to distinguish between preventing problems in financial markets from spilling over to the real economy and trying to directly control asset prices. Most policymakers

\footnotetext{
5 Of course, declines in stock prices can also affect the economy by reducing wealth and consumption. But such a reduction in consumption can be a rational, optimal response to revisions in expected future income. In contrast, the credit market problems discussed in the text are market imperfections due to asymmetric information, which can be aggravated by a sudden fall in stock prices.

6 President Wilson signed the Federal Reserve Act on December 23, 1913. Dwyer and Gilbert (1989) argue that bank panics did not cause recessions but that they might have exacerbated the consequences of such slowdowns.

7 The creation of the Federal Deposit Insurance Corporation (FDIC) in 1934 was a very important part of the solution to banking panics.
}

believe that the Fed should not try to target asset prices_like stocks—or prevent their adjustment.

I believe it is very important that the Federal Reserve not take a position per se on the level of prices in asset markets, especially the stock market. It is very easy to be wrong about the appropriate level; this judgment ought to be left to the market.

-William Poole, President of the Federal Reserve Bank of St. Louis (2001)

Indeed, leaving aside the question of whether the Federal Reserve knows the fundamental value of stocks, the Fed's tools might be inappropriate for the task. The Federal Reserve potentially has two tools with which it could influence stock prices: (i) It could use open market operations to influence stock prices through interest rates, or (ii) it could administratively adjust margin requirements for stock markets. ${ }^{8}$ Margin requirement changes have been rare in recent history, so their effects are not well understood. And monetary policy is a very blunt instrument with which to change equity prices. It might require large changes in interest rates - with commensurate changes in prices, output, and employment - to change equity prices to any substantial degree. Although central banks cannot target stock prices, they can mitigate the disruptive effects that stock price corrections can have on the real economy.

\section{Short-, Medium-, and Long-Term Policy Reactions}

It is useful to break down the effects of crises into short-term effects on liquidity, medium-term business cycle effects on output and inflation, and long-term effects on consumption and production. As discussed, the uncertainty that crises produce often necessitates immediate provision of additional liquidity to the financial system. In the medium term, central banks often find it useful to maintain lower interest rates than they otherwise would, to safeguard business conditions and keep banks and other financial institutions healthy. Although regulators seek to make bank portfolios relatively insensitive to changes in interest rates, banks still tend to have short-term liabilities and long-term assets. Therefore,

8 The margin requirement is the cash-to-value ratio needed to purchase a given amount of stocks. In other words, a 20 percent margin requirement means that - at most -80 percent of a stock's purchase price may be borrowed. 
declining short-term interest rates usually improve bank balance sheets.

Finally, the underlying causes of crises can often have long-term effects on the economy. For example, the terrorist attacks of September 11, 2001, led to increased demand for defense and security. Resources that would have been spent on other needs-consumption of health care, durable goods, investment, etc. - went instead to prevent further attacks. These effects lie outside the Fed's major macroeconomic mission, to contribute to maximum sustainable economic growth by maintaining low and stable inflation. There is little that a central bank can or should do about such long-run effects.

\section{Provision of Liquidity}

Financial crises are almost synonymous with a lack of liquidity - that is, when financial firms have assets that they cannot convert quickly to cash to make payments. The traditional job of central banks, such as the Federal Reserve, is to provide extra liquidity in times of crisis. The Federal Reserve can provide extra liquidity several ways: (i) The Fed can buy assets, usually Treasury securities, providing banks with greater reserves and lowering the federal funds rate; (ii) the Fed can lend directly to banks through the discount window, again providing them with greater reserves; and (iii), as a regulator, the Fed can encourage banks to loan money more freely-it can engage in regulatory forbearance.

\section{Measuring Monetary Policy with the Taylor Rule}

One would like to distinguish the Federal Reserve's direct reactions to a crisis from its reaction to the economic conditions that caused the crisis, or its indirect reaction to the effects of the crisis on output and inflation. For example, in the aftermath of the September 11th terrorist attacks, one would like to disentangle the Fed's reaction to the effect on liquidity and public confidence from the Fed's reaction to the recession that was going on at that time. To distinguish the Fed's reaction to a crisis itself from its normal reaction to prevailing economic conditions, one needs a model for the Fed's usual response to economic conditions.

There have been many attempts to model the Fed's normal behavior, but the most popular is the Taylor rule (Taylor, 1993). Taylor set out to model how the Federal Reserve had recently set short-term interest rates in response to a small set of particularly important economic variables: the Fed's desired inflation target, current output, and current inflation. The version of the Taylor rule used in this paper is as follows:

(1) $f_{t}^{*}=2.5+\pi_{t-1}+\frac{\left(\pi_{t-1}-\pi^{*}\right)}{2}+100 \cdot \frac{\left(y_{t-1}-y_{t-1}^{P}\right)}{2}$,

where $f_{t}^{*}$ is the predicted federal funds rate from the Taylor rule; $\pi_{t}$ is the year-over-year inflation rate in percentage terms, calculated from the gross domestic product (GDP) deflator; $y_{t}$ is the log of real GDP; $y_{t}^{P}$ is the log of potential real GDP; and $\pi^{*}$ is the Fed's target inflation rate. ${ }^{9}$ Potential GDP is the predicted value from a log linear trend model of GDP with a break in trend growth permitted in 1972.

The Taylor rule is clearly a simplification of the Fed's behavior; the Federal Open Market Committee (FOMC) looks at a wide variety of indicators in making policy. But Taylor (1993) found that (1) described the Fed's behavior during the 1980s and 1990s fairly well while using variables (output and inflation) that are parts of the Fed's legal mandate. Later research confirmed that the rule stabilizes output and inflation well in many economic models and even describes the behavior of central banks around the globe pretty well (Taylor, 1998; Gerlach and Schnabel, 2000; Rudebusch and Svensson, 1998; Levin, Wieland, and Williams, 1999; and Judd and Rudebusch, 1998).

Orphanides (2001), however, points out a potential problem with evaluating policy with the Taylor rule: Economic data are usually revised after their initial release, and economic conditions viewed with revised data can look very different from conditions viewed with the initial data. Therefore, Orphanides (2001) argues that, to understand policymakers' actions, one should use real-time data, the latest data available to the policymakers at the time policy was made.

The top panel of Figure 2 shows the predicted federal funds rate, using real-time data, for Taylor rules with inflation targets of 0,2 , and 4 percent, along with the actual federal funds rate. The highest dashed line indicates the Taylor rule prediction for an inflation target of 0 percent, and the lowest dashed line indicates the Taylor rule prediction for an inflation target of 4 percent. The bottom panel of the same figure shows the actual federal funds

\footnotetext{
9 This version of the Taylor rule is similar to that used in the Federal Reserve Bank of St. Louis Monetary Trends except that it uses the GDP deflator instead of the personal consumption expenditures deflator to measure inflation and real-time data instead of final data.
} 


\section{Figure 2}

\section{Federal Funds Rate and Taylor Rule Predictions}
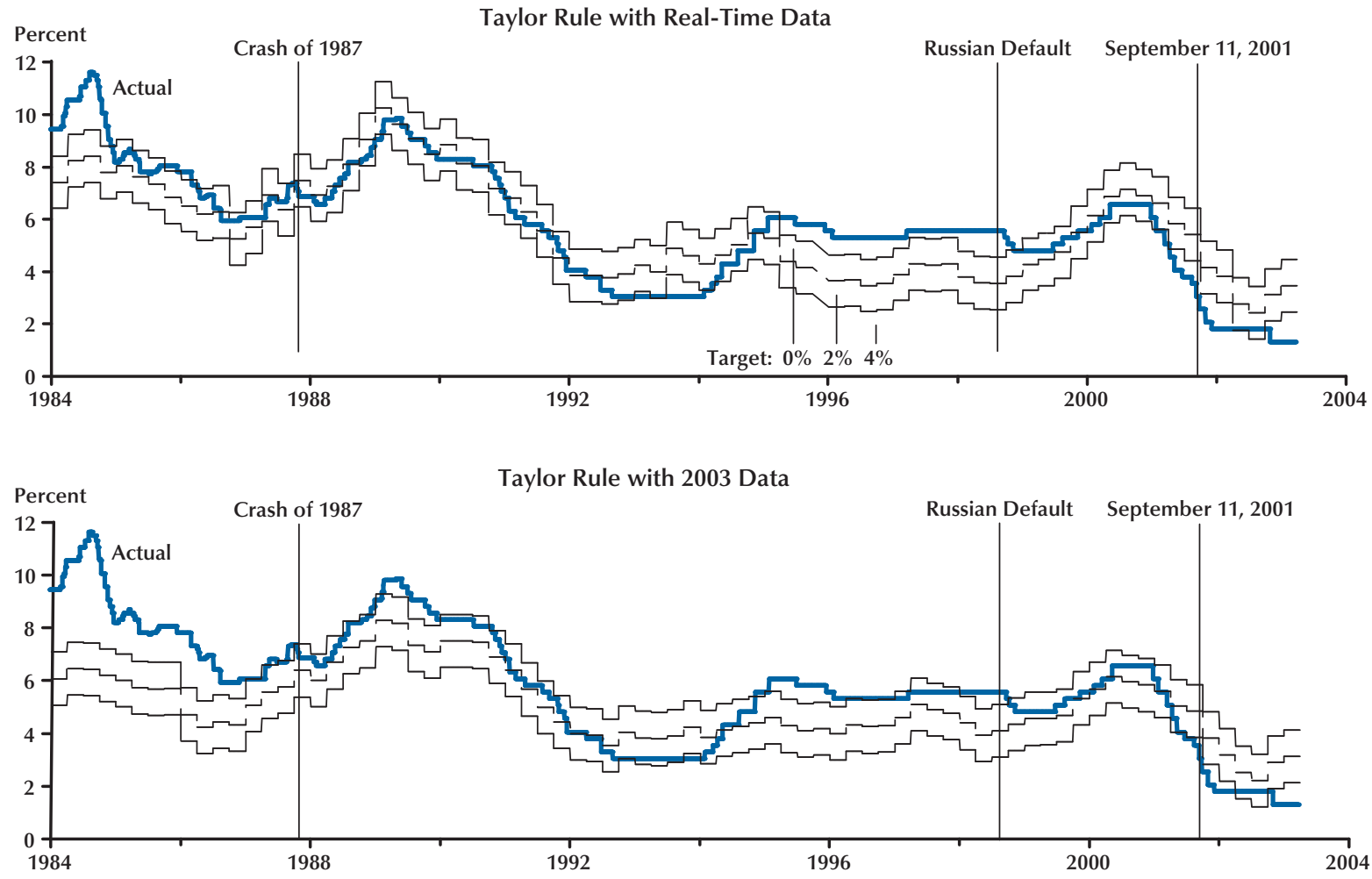

NOTE: Top panel: Federal funds rate target (solid blue line) and targets implied by Taylor rules with inflation targets of 0 (top black line), 2 (middle black line), and 4 percent (bottom black line), using real-time data (output and inflation data that would have been available at approximately the time policy was made). Bottom panel: Same figures but using final revised 2003 data to calculate output and inflation. Vertical lines show the dates of crises studied in this article.

rate with predicted values, using ex post (2003) data to compute the implied funds rates. The Taylor rule appears to describe the federal funds rate fairly well with either type of data. The real-time data makes the Taylor rule fit much better for the period 1984 to 1990 , but it also makes actual late-1990s policy look much tighter (consistent with a lower inflation rate) than does the 2003 data. The vertical lines in the panels depict the dates of the crises that are examined in this paper: The stock market crash of October 19, 1987; the Russian government's default on its debt on August 11, 1998; and the September 11, 2001, terrorist attacks.

Of course, Figure 2 also makes it plain that the Taylor rule approximates the Fed's behavior fairly imprecisely. From 1994 to 1996, for instance, the implied Fed inflation target fell from more than 4 percent to less than zero. Clearly, this doesn't reflect changes in the Fed's actual preferences for inflation but rather is simply due to the fact that the simple Taylor rule omits some important determinants of the federal funds rate target. As one compares the actual funds rate changes with the Taylor rule predictions, one should keep in mind the crudeness of the approximation.

\section{CASE STUDIES}

\section{The Stock Market Crash of October 19, 1987}

There has been much debate on the causes of the crash of October 1987. The Brady Commission, headed by former Senator-later Treasury Secretary-Nicolas F. Brady, blamed portfolio insurance and program trading for the size of the $1987 \mathrm{crash}$. The Commission also found that specialists were partly to blame for selling into the crash rather than buying to ease the crash. Santoni (1988) argues that analysis of high-frequency data shows that program 
trading and portfolio insurance were not to blame for the size of the 1987 crash. Rather, the article concludes that the crash was a rational reaction to fundamental news about stocks, though it does not make a case for what that news might have been.

Some analysts blamed monetary policy for contributing to the crash, but there was little agreement on the nature of the problem. Roberts (1987), for example, argued that tight monetary policy caused the crash. Canto and Laffer (1987), on the other hand, argued that monetary policy was too loose, citing growth in the monetary base. Short-term interest rates indisputably were rising prior to the crash of 1987 , and stock markets tend to do poorly (well) when interest rates rise (fall) (Jensen, Mercer, and Johnson, 1996; and Thorbecke, 1997). By itself, this would argue for Roberts's (1987) view. Of course, rising interest rates do not, by themselves, cause stock prices to crash, but they may have been one factor in the bust.

In the two months prior to the crash, stock markets experienced significant losses. For example, the top panel of Figure 3 shows that from August 25 to October 16, 1987, the S\&P 500 lost about 16 percent of its value. On October 19, 1987, stock prices fell precipitously: The S\&P 500 plunged by 20 percent and the Dow Jones Industrial Average sank more than 500 points, the largest one-day decline in stock market history. Panel 2 in Figure 3 shows that the 30-day implied volatility of stock prices rose enormously as stock prices dropped. Implied volatility measures the uncertainty about future stock prices obtained by equating options prices with those from a theoretical option pricing formula, such as the Black-Scholes formula. As such, it is synonymous with market perceptions of price risk. Implied volatility (as shown in Figure 3) remained high for many months following the stock market crash. Panels 3 and 4 in Figure 3 show that bond yields fell (bond prices rose) as investors sought safe haven from the volatile stock market; and the trade-weighted foreign exchange value of the dollar slid after the crash as nervous investors fled U.S. assets.

The stock market crash had potentially serious effects in both the short and long term. Over the short term, the price drop created an enormous problem for brokerage houses and market specialists. Many specialists and large securities firms reportedly had accumulated unusually large inventories of stock, for which they must pay five days later. ${ }^{10}$ To make payment, these financial firms needed to borrow money. The volatility and low level of stock prices made the stock itself poor collateral, however, and banks were reluctant to provide further credit to the specialists and brokerage houses with their solvency in doubt. The financial services industry faced widespread bankruptcy that would have had serious repercussions for the real economy through its impact on the payments system and financial intermediation. Stewart and Hertzberg (1987) detail the events of the crash of October 19, 1987.

Immediately after the crash, Chairman Greenspan announced the Federal Reserve System's "readiness to serve as a source of liquidity to support the economic and financial [system]" (Stewart and Hertzberg, 1987). The Fed poured liquidity into markets by lending directly through the discount window, by buying Treasury securities (open market operations), and by encouraging banks to lend to Wall Street. ${ }^{11}$ Policy was implemented with unusual flexibility to ensure adequate liquidity. On several occasions, for example, the Fed's Open Market Desk entered the market to supply reserves before its customary time of the day for open market operations (Sternlight and Krieger, 1988). A convenient measure of the degree of liquidity provided to the market in this period is excess reserves (total reserves less required reserves). Table 1 shows that excess reserves rose to the unusually high level of almost $\$ 1.6$ billion in the reserve period ending November 4 , 1987.

In the weeks that followed, the Federal Reserve continued to ease pressure in money markets, lowering interest rates. Panel 5 of Figure 3 shows that the Fed lowered the federal funds target, which influences all short-term interest rates, several times in the four months following the crash, for a total reduction of about 80 basis points. ${ }^{12}$ Compared with the Taylor rule predictions calculated from the output gap and inflation, short-term interest rates did decline; monetary policy was eased beyond what one might have expected from the output and inflation at the time. ${ }^{13}$

\footnotetext{
${ }^{10}$ The New York Stock Exchange (NYSE) clearance and settlement cycle is now three days.

${ }^{11}$ Calomiris (1994) provides a comprehensive discussion of the uses of the discount window.

${ }^{12}$ In 1987 the Federal Reserve described its policies in terms of "money market conditions" rather than explicit federal funds rate targets. The Federal Reserve Bank of New York, however, provides federal funds rate target data back to 1980 .

${ }^{13}$ A standard to judge unusually large changes would be desirable. Given the substantial movements around the Taylor series targets (in Figure 2), however, formal statistical tests would have little power to reject the null that changes during crisis periods are of normal size. Therefore this paper retains an informal approach.
} 


\section{Figure 3}

Data Around the Time of the Stock Market Crash of October 19, 1987
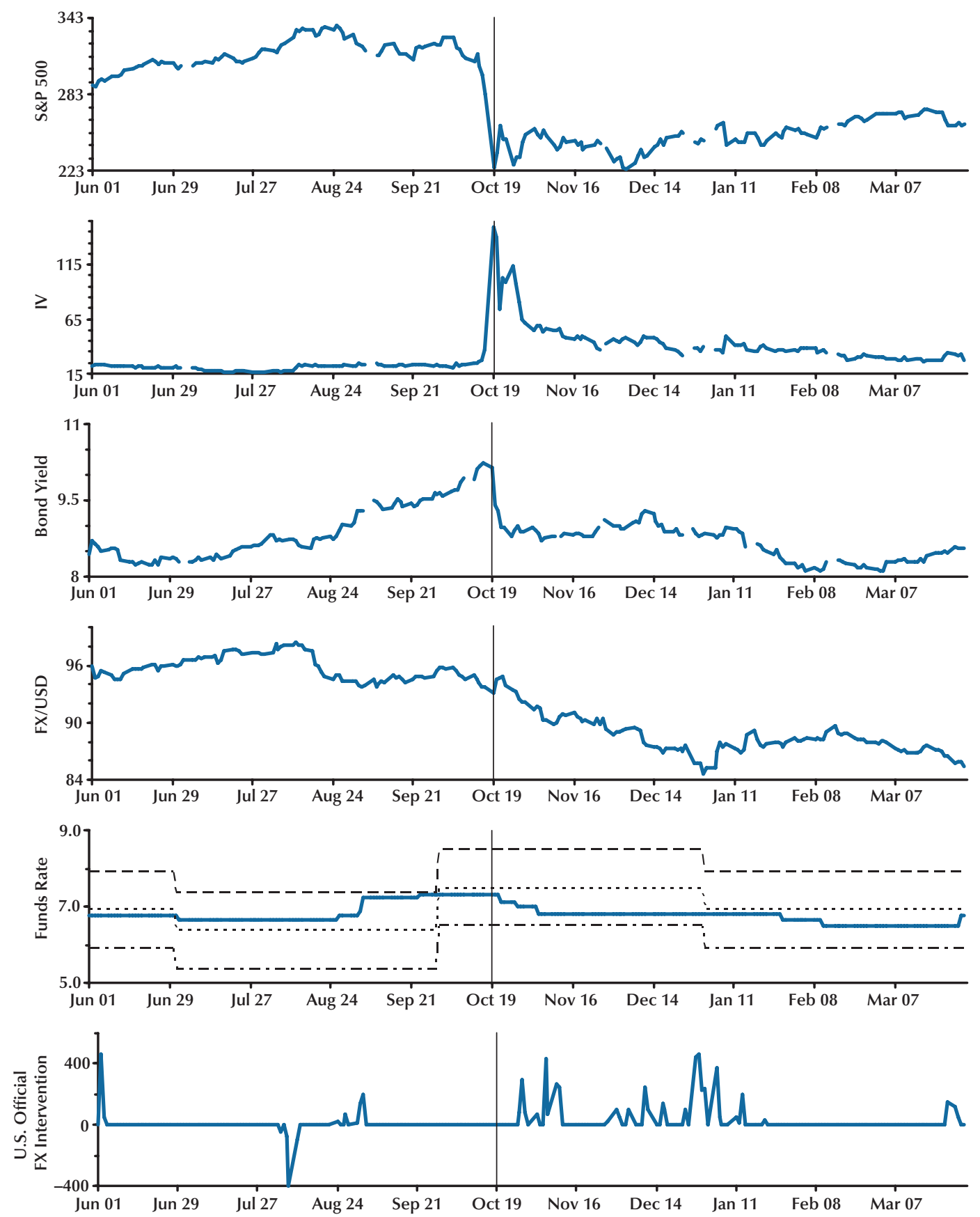

NOTE: Daily financial data around the time of the stock market crash of October 19, 1987. The first five panels show the S\&P 500 index, the NYSE implied volatility from options prices, the yield on 10-year U.S. government bonds, the trade-weighted value of the dollar, and the federal funds rate target (solid blue line) and the targets implied by Taylor rules with inflation targets of 0 (top dashed line), 2 (middle dotted line), and 4 percent (bottom dashed-dotted line) (using real-time data). The final panel shows U.S. official foreign exchange intervention, in purchases of millions of dollars. The vertical line denotes the date of the stock market crash, October 19, 1987. 


\section{Table 1}

\section{Provision of Liquidity in Response to the Stock Market Crash of October 19, 1987}

\section{Reserve maintenance period ending}

September 9, 1987

September 23, 1987

October 7, 1987

October 21, 1987

November 4, 1987

November 18, 1987

December 2, 1987

December 16, 1987

December 30, 1987

\section{Excess reserves}

1,194

515

833

967

1,561

492

1,213

1,206

806
NOTE: Values show excess reserves (total bank reserves less required reserves) in millions of dollars for the two-week reserve maintenance periods around the stock market crash of October 19, 1987.

SOURCE: Sternlight and Krieger (1988).

In the medium term, the stock market crash reduced the wealth of shareholders, who might have been expected to reduce their consumption. Such an expectation would, in turn, tend to reduce business investment and employment. This uncertainty about future economic activity would further reduce output by limiting the consumption of people who did not hold stock, but who might be concerned about their future employment.

In fact, there was relatively little impact on consumption from the crash of 1987 . This might be due to the recovery of stock prices-prices were back to pre-crash levels within two years-or the fact that the rapid runup in stock prices early in the year meant that people had not adjusted their consumption upward, so there was little downward effect from the crash.

Stock prices went up so rapidly this year that people didn't know how rich they were.

Now, many of them don't know how poor they are.

-Franco Modigliani, Nobel Prize laureate for research on consumption, quoted in Stewart and Hertzberg (1988)

The bottom panel of Figure 3 illustrates another policy response to the crash in which the Fed partici- pated: foreign exchange intervention. ${ }^{14}$ The turmoil in the stock market combined with speculation that U.S. and foreign authorities no longer wanted to stabilize the dollar contributed to a falling dollar. ${ }^{15}$ In response, the Federal Reserve Bank of New York purchased several hundred million U.S. dollars on foreign exchange markets, on behalf of the Treasury and the Federal Reserve. This action was intended to stabilize the dollar during its post-crash decline, though it is not clear that it had such an effect (see panel 4 of Figure 3).

In the wake of these policy actions, stock prices recovered and implied volatility declined as markets returned to normal conditions in the following months. (Hafer and Haslag, 1988, discuss the FOMC's reaction to the stock market crash.) It is generally agreed that the Fed's prompt action prevented a financial meltdown.

The financial system would have ceased to function were it not for the central bank's broad interpretation of its responsibilities as the ultimate source of liquidity.

-William L. Silber, letter to The Wall Street Journal, February 23, 1998

\section{The Russian Default}

In the mid-1990s, Russia struggled with the burdens of mostly negative economic growth, massive debt inherited from the Soviet era, and an inefficient tax system (Chiodo and Owyang, 2002). At the same time, Russia attempted to maintain a target zone exchange rate against the U.S. dollar. The Asian crisis of July 1997 made international investors even more cautious about investing in developing economies (like Russia). Moreover, Russia's fiscal situation worsened in 1998 as oil prices fell-Russia is a major oil exporter - and the Russian Duma (the legislature) failed to pass appropriate tax reform legislation.

Fiscal concerns posed a real problem for the

\footnotetext{
${ }^{14}$ Foreign exchange intervention is the practice of monetary authorities buying and selling currency in the foreign exchange market to influence exchange rates. In the United States, for example, the Federal Reserve and the U.S. Treasury generally collaborate on foreign exchange intervention decisions, and the Federal Reserve Bank of New York conducts operations on behalf of both. Neely $(1998,2000)$ discusses foreign exchange intervention in more detail.

15 On February 22, 1987, there had been an international agreement, called the Louvre Accord, to stabilize the dollar. By late October, currency traders were unsure whether or not this agreement was still in effect.
} 
maintenance of the exchange rate because fiscal deficits must be financed by some combination of borrowing and monetization-expanding the money supply. ${ }^{16}$ And the limited appetite of foreign investors to hold more Russian debt meant that fiscal deficits would ultimately translate into an expanded money supply. Expanding the money supply would increase the Russian price level (in rubles), making Russian goods more expensive on world markets and reducing the real quantity of rubles demanded to buy those goods. This fall in demand would increase pressure for a devaluation of the ruble, which would lead to a capital loss for foreign investors in Russian assets.

Because financial markets are forward looking, the prospects of such a capital loss in the future led investors to question the ability of the Russian government to honor its debts and they began withdrawing their capital from Russia. ${ }^{17}$ As demand for Russian assets fell, Russian interest rates rose and stock prices fell. On August 11, 1998, the Russian government stopped trying to fix the value of the ruble (i.e., it allowed the ruble to float), defaulted on domestic debt, and halted payments on its foreign debt.

After the Asian crisis and the Russian default, international investors saw greater risk in emerging market debt and began to seek safer assets in which to invest their money. Spreads between yields on more- and less-safe assets widened around the globe, as investors considerably revised their assessment of the dangers of investing in developing countries. A key factor in rising perceptions of risk was the fact that the International Monetary Fund (IMF) chose not to bail out Russia, as it had done for Bulgaria, Thailand, and Mexico. Prior to August 1998, Russia had been considered too important for the IMF to forego assisting it in a payments crisis. Emerging market funds sold some of their positions in profitable countries to meet margin calls on their Russian positions. These sales further widened the spreads between securities in emerging and developed countries.

The Russian default had potentially important implications for U.S. economic policy. The flight of

\footnotetext{
${ }^{16}$ The reader might wonder if U.S. fiscal deficits would also cause monetization and inflation. The U.S. government is in far better fiscal condition than the Russian government was.

${ }^{17}$ Neely (1999) offers an introduction to the problems of capital flightthe withdrawal of assets from a country-and capital controls-legal constraints on international trade in assets.
}

investors to safer assets can be seen in the top panel of Figure 4, which displays the falling yields on 10year U.S. bonds after the Russian default. At the same time, U.S. equity prices declined and their implied volatilities rose threefold from pre-crash levels (panels 2 and 3 of Figure 4). The foreign exchange value of the dollar rose briefly after the default, only to decrease as uncertainty in U.S. equity markets increased and the likelihood increased that the FOMC would cut the federal funds target (panel 4 of Figure 4). ${ }^{18}$ Indeed, the dollar did fall farther, temporarily, following the period of federal funds target cuts in the fall.

In making policy in the wake of the Russian default, the Fed lowered short-term U.S. interest rates to minimize the consequences of international financial conditions for the U.S. economy and to ameliorate those conditions abroad. By lowering short-term interest rates, central banks of industrialized economies created greater demand for imported goods and also lowered international borrowing costs. Lower interest rates for emerging economies ultimately might raise U.S. exports and the earnings of U.S. firms.

After two rate hikes in September and October, however, some feared that the November easing would encourage unrealistically high U.S. equity market valuations, which had had several years of very strong performance and were overvalued by traditional measures such as price-earnings ratios.

... the Federal Reserve chairman has a tricky task. He must bring the US economy and stock market off their highs - without provoking a panic... Risk premiums in bond markets have shrunk since the last cut, while stock markets have soared...the cut risks stoking the boom.

-Lex column: "Greenspan's Bubble,"

November 18, 1998, Financial Times

Any effect of this third cut on equity valuations was almost certainly marginal, outweighed by the insurance effect on the real economy.

In all, the FOMC reduced the funds rate target by 75 basis points over the four months following the Russian default (panel 5 of Figure 4). While these funds rate reductions in the wake of the 1998 Russian default were persistent, the funds target

\footnotetext{
18 Tensions with Iraq and the Long-Term Capital Management (LTCM) collapse were also cited as contributing to the dollar's vulnerability.
} 


\section{Figure 4}

\section{Data Around August 11, 1998, the Russian Default}
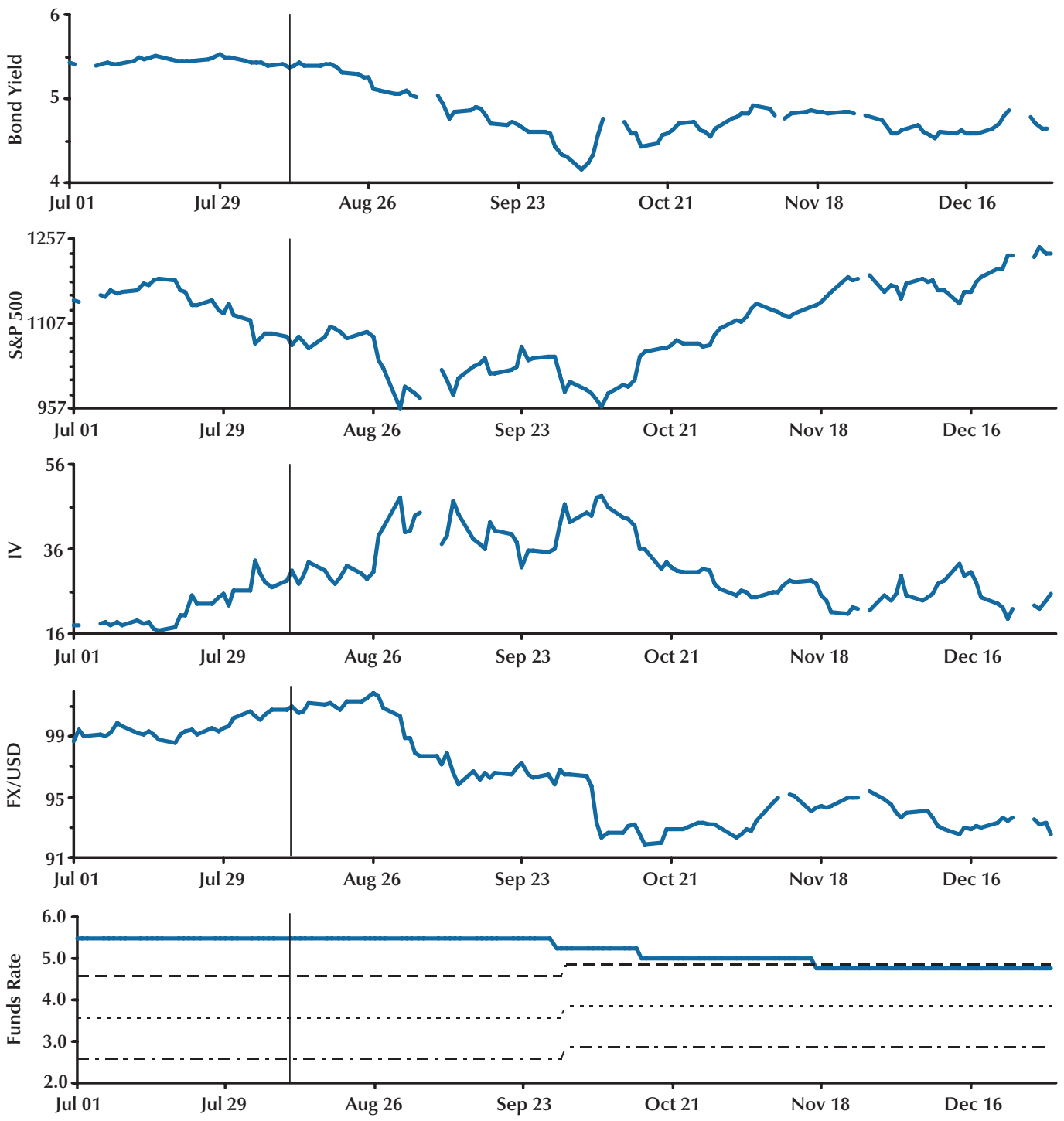

NOTE: Daily financial data around the time of the Russian default in August 1998. The first four panels show the yield on 10-year government bonds, the S\&P 500 index, the NYSE implied volatility from options prices, and the trade-weighted value of the U.S. dollars. The final panel shows the federal funds rate target (solid blue line) and the targets implied by Taylor rules with inflation targets of 0 (top dashed line), 2 (middle dotted line), and 4 percent (bottom dashed-dotted line) (using real-time data). Vertical lines show August 11, 1998, the date of the Russian default. 
remained consistent with a very low U.S. inflation target at any point. These reductions helped to insulate the U.S. economy from the asset market turbulence of the default. ${ }^{19}$ Financial markets remained volatile throughout 1998 until interest rate reductions by the central banks of several developed countries took effect (see implied volatility in panel 3 of Figure 4).

Among the casualties of the Russian default was the highly leveraged hedge fund, Long-Term Capital Management (LTCM). LTCM followed a "convergence-arbitrage" strategy in which it examined closely related assets, buying the apparently cheaper asset and selling the overpriced asset. To make money from extremely small disparities in prices, LTCM was very highly leveraged, making it vulnerable to small losses. That strategy was very profitable for several years and led to the narrowing of these disparities in prices. But the LTCM strategy was predicated on the belief that very similar assets must ultimately converge to the same price. There is twoway risk, however. Often the price difference for similar assets is due to differences in liquidity, and such a difference would only increase in times of stress, such as a default. The Russian default caused very large, protracted differentials in the prices of the assets that LTCM was attempting to arbitrage. ${ }^{20}$

While the failure of a financial firm and the bankruptcy of its owners is not ordinarily a matter of concern for a central bank, LTCM was so large and deeply leveraged that a disorderly demise presented the possibility of cascading failures of its many creditors. Concerned about the stability of the financial system, the Federal Reserve Bank of New York facilitated a meeting of LTCM creditors (banks) on September 23, 1998, in which those banks agreed to provide additional capital in exchange for 90 percent of the firm's stock. No public money was used or put at risk in the transaction. The purchase simply permitted an orderly dissolution of LTCM's assets. The new investors allowed the original owners to retain a 10 percent stake in the firm to induce them to assist in the liquidation of LTCM's assets (Greenspan, 1998).

\footnotetext{
${ }^{19}$ Saidenberg and Strahan (1999) argue that U.S. firms' lines of credit with banks helped to cushion those borrowers from sharp rises in commercial paper rates in the wake of the Russian default.

${ }^{20}$ Jorion (2000) examines LTCM's strategy and mistakes in some detail. Greenspan (1998) reports on the Fed's role in the LTCM bailout.
}

\section{The September 11th Terrorist Attacks}

On September 11, 2001, 19 Al Qaeda terrorists hijacked 4 airline flights within the United States. Two of those planes were deliberately flown into the twin towers of the World Trade Center, at the heart of U.S. financial markets. A third was flown into the Pentagon. The fourth crashed southeast of Pittsburgh, Pennsylvania, during a struggle between the terrorists and passengers as the latter successfully sought to prevent the terrorists from reaching targets in Washington, DC. The September 11th terrorist attacks on the World Trade Center and the Pentagon not only brought about a human tragedy that caused approximately 3000 deaths (Hirschkorn, 2003) but also had potentially serious ramifications for the economy and monetary policy.

The immediate effects of the attacks included the disruption of the payments system, a one-week closure of the NYSE, and a temporary suspension of air flights within the United States. The first two panels of Figure 5 show that U.S. stock prices fell, and the implied volatility of equities rose and remained high for several months. So, there was both direct physical disruption of the financial system and the liquidity effects of a stock market crash. ${ }^{21}$ As discussed earlier, falling asset prices and heightened uncertainty often lead banks and other intermediaries to reduce or halt lending.

Initially, the Federal Reserve sought to restore confidence and avoid significant disruption to the payments and financial system by providing liquidity in a number of ways: repurchase agreements by the New York desk (repos); direct lending through the discount window; extension of float; swap lines to permit foreign central banks to meet liquidity needs in U.S. dollars; and repeated reductions in the federal funds rate in the weeks following the attacks (Neely, 2002; Lacker, 2003).

The extension of credit through the float requires some explanation. When a bank presents a check to the Fed for clearing, the presenting bank may be credited with the amount of the check before the paying bank is debited. Float is the money that has been credited to receiving banks before being debited from paying banks; it is a loan by the Federal Reserve to the banking system. The September 11th attacks resulted in the suspension of air transport, greatly slowing check clearing operations. The Fed, however,

\footnotetext{
21 McAndrews and Potter (2002) study the liquidity effects of the attacks in some depth. Fleming and Garbade (2002) look at settlement issues. Lacker (2003) takes a close look at the payments system disruptions.
} 


\section{Figure 5}

\section{Data Around the September 11, 2001 Terrorist Attacks}
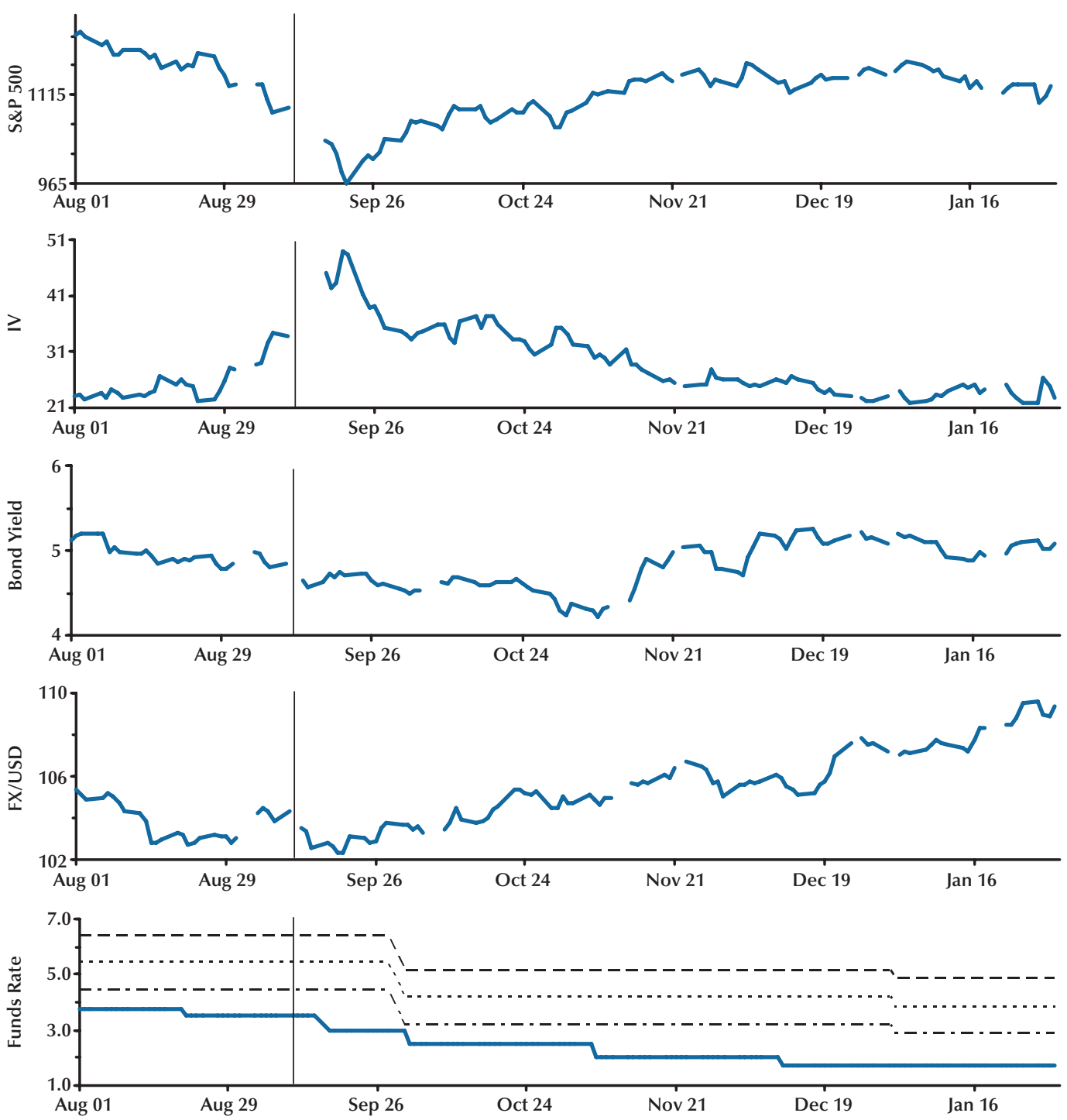

NOTE: Daily financial data around the time of the September 11th terrorist attacks. The first four panels show the S\&P 500 index, the NYSE implied volatility from options prices, the yield on 10-year U.S. government bonds and the trade-weighted value of the U.S. dollar. The first panel shows the federal funds rate target (solid blue line) and the targets implied by Taylor rules with inflation targets of 0 (top dashed line), 2 (middle dotted line), and 4 percent (bottom dashed-dotted line) (using real-time data). The vertical lines show September 11, 2001. 


\section{Table 2}

\section{Provision of Liquidity in Response to September 11, 2001}

\begin{tabular}{|c|c|c|c|c|}
\hline Wednesday figures & Repos & $\begin{array}{c}\text { Discount window } \\
\text { lending }\end{array}$ & Float & $\begin{array}{c}\text { Deposits at } \\
\text { Federal Reserve Banks } \\
\end{array}$ \\
\hline Average July 4 to Sep 5 & 27,298 & 59 & 720 & 19,009 \\
\hline Sep 12 & 61,005 & 45,528 & 22,929 & 102,704 \\
\hline Sep 19 & 39,600 & 2,587 & 2,345 & 13,169 \\
\hline Sep 26 & 51,290 & 20 & $-1,437$ & 18,712 \\
\hline Oct 3 & 32,755 & 0 & 173 & 14,376 \\
\hline Oct 10 & 33,505 & 46 & 5,306 & 20,986 \\
\hline Oct 17 & 37,045 & 1 & 1,623 & 27,395 \\
\hline Oct 24 & 30,050 & 42 & 654 & 18,746 \\
\hline
\end{tabular}

NOTE: Data (in millions of U.S. dollars) were taken from the Board of Governors' H.4.1 releases, July 5 to October 25, 2001. Repos, Discount window lending and Float are labeled "repurchase agreements," "adjustment credit," and "float," respectively, in "factors supplying reserves." Deposits at Federal Reserve Banks are the sum of "service related balances and adjustments" and "reserve balances with F.R. Banks."

decided to continue to credit the reserve accounts of banks as usual, passively extending this loan to the banking system. Table 2 shows that float rose substantially just after September 11, 2001.

The level of deposits at Federal Reserve Banks summarizes the liquidity provided to the economy. On September 12, this measure stood at $\$ 102$ billion, more than five times the average of the previous ten Wednesdays (see Table 2). Within three weeks, however, the available liquidity figures - repos, discount lending, float, and deposits at Federal Reserve Banks - were indistinguishable from preattack figures.

Panels 3 and 4 of Figure 5 show that 10-year bond yields fell (bond prices rose) and the foreign exchange value of the dollar at first declined but then rose strongly for several months. Initially, the dollar declined somewhat as the direct attack on the United States more than offset the usual safe-haven reputation of U.S. assets. Over the next few months, however, the dollar appreciated significantly.

Analysts cited three factors that bolstered the value of the dollar during this period: better-than-expected U.S. economic performance, short-term interest rate cuts by the world's major central banks, and successful military operations in Afghanistan.

Over the medium term, the attacks generated great uncertainty about further attacks and the steps necessary to prevent further attacks. These fears manifested themselves immediately in sharply higher implied volatility for stocks and depressed consumer confidence. The atmosphere reduced consumption and investment and exacerbated the incipient economic slowdown.

Forecasters almost unanimously predicted that the attacks would exacerbate the developing slowdown through their effect on consumer confidence, asset prices, and transitory dislocations in transportation, law enforcement, defense spending, communications (mail), etc. For example, Macroeconomic Advisers revised their pre-attack forecast for 2001 growth down from 0.9 percent to -0.6 percent in the wake of the attacks. This effect was expected to be partially reversed in 2002 ; the post-attack Macroeconomic Advisers 2002 forecast was revised upward from 3.0 percent to 4.1 percent.

Complicating the Fed's policy decision problem, the unusual nature of the disruption to the payments systems, air transport, and other sectors meant that the September and October economic statistics provided less information than usual regarding longer-run trends. The final panel of Figure 5 shows that the FOMC lowered the federal funds rate target by 175 basis points in the three months following September 11th. Monetary policy was already fairly accommodative by the metric of the Taylor rule predictions, however, and the reductions in the funds target served only to maintain this accommodative stance, not to increase it. In other words, the Taylor rule called for lower rates, and the actual rate reductions only kept pace with the rule's prescription. 
The long-term economic effects of the attacks can be classified into wealth effects and tastetechnology shocks. Over this horizon, investment must rise and consumption must ultimately fall a bit to replace much of the destroyed physical and human capital. Bram, Orr, and Rapaport (2002) estimate that the property damage, cleanup, and earnings losses of the destruction of the World Trade Center range from $\$ 33$ to 36 billion through June 2002. Spending on law enforcement and defense activities will rise and-as they are mostly public goods-so will the taxes to pay for them. For example, the war in Afghanistan is a direct result of the terrorist attacks. Such costs are hard to measure because one doesn't know what defense or law enforcement costs would have been in the absence of the attacks. Kogan (2003), however, estimates that the total cost to the federal government from the September 11 attacks, homeland security, and the wars in Afghanistan and Iraq will be about $\$ 220$ billion, from 2001 through 2004.

In addition to these direct losses, the attacks imposed more subtle costs on the economy. By raising the costs associated with activities such as travel, security, and insurance, the attacks will shift resources among industries. In this sense, the attacks might be viewed as a negative productivity shock, as more resources will be required to produce the same product. That is, travelers will require more security to fly to Memphis and IBM will pay a higher cost for a given level of property insurance for a downtown office building. These costs are very difficult to measure.

Given the enormous size and productivity of the U.S. economy, the costs imposed by the September 11 th attacks will have only the most marginal impact on the U.S. standard of living (Hobijn, 2002). For example, the direct cost to the federal government ( $\$ 220$ billion) is only about one-half of 1 percent of U.S. output from 2001 through 2004.

\section{DISCUSSION AND CONCLUSION}

The stock market crash of 1987 and the September 11th attacks posed substantial potential dangers to the economy through disruption of the payments system and financial markets. The stock market crash generated liquidity problems through dramatically lower stock prices and greatly increased uncertainty. The September 11th attacks, too, resulted in lower asset prices and much higher uncertainty, but they also physically disrupted the payments and financial system. In both cases, the Federal Reserve provided immediate liquidity to ensure that the payments system continued to function and eased short-term interest rates for some time, to reduce the pressure on the financial system and protect real economic activity.

The Russian default had less dramatic effects on the United States, but still posed potential problems to U.S. financial markets through dramatically higher risk premia. The episode probably led the Fed to maintain lower short-term interest rates than would otherwise have been the case. Also, the Fed helped to facilitate the orderly dissolution of LTCM, a large hedge fund, to help ensure the continuing functioning of financial markets.

In some ways, however, the monetary policy response to all three of these experiences was similar to the response to bank panics that the Federal Reserve System was created to handle. Falling asset prices and heightened uncertainty can prompt banks to reduce or halt customary lending to financial markets just when that capital is most needed. The stock market crash of 1987 , the Russian default of 1998, and the attacks of September 11, 2001, all threatened the health of the U.S. economy through their potential impact on the financial system. In response to these recent financial crises, the Fed has functioned as a lender of last resort, much as the authors of the Federal Reserve Act intended more than 90 years ago.

\section{REFERENCES}

Bernanke, Ben and Gertler, Mark. "Agency Costs, Net Worth, and Business Fluctuations." American Economic Review, March 1989, 79(1), pp. 14-31.

Bram, Jason; Orr, James and Rapaport, Carol. "Measuring the Effects of the September 11 Attack on New York City." Federal Reserve Bank of New York Economic Policy Review, November 2002, 8(2), pp. 5-20.

Calomiris, Charles W. "Is the Discount Window Necessary? A Penn Central Perspective.” Federal Reserve Bank of St. Louis Review, May/June 1994, 76(3), pp. 31-55.

Calomiris, Charles W. and Hubbard, R. Glenn. "Firm Heterogeneity, Internal Finance, and 'Credit Rationing', Economic Journal, March 1990, 100(399), pp. 90-104.

Canto, Victor A. and Laffer, Arthur B. "Monetary Policy Caused the Crash-Not Tight Enough." The Wall Street Journal, October 22, 1987.

Chiodo, Abbigail J. and Owyang, Michael T. "A Case Study 
of a Currency Crisis: The Russian Default of 1998." Federal Reserve Bank of St. Louis Review, November/ December 2002, 84(6), pp. 7-17.

Dwyer, Gerald P. and Gilbert, R. Alton. "Bank Runs and Private Remedies.” Federal Reserve Bank of St. Louis Review, May/June 1989, 71(3), pp. 43-61.

Federal Reserve Bank of Minneapolis The Region, 75th Anniversary Issue, August 1988, 2(2).

Fleming, Michael J. and Garbade, Kenneth D. "When the Back Office Moved to the Front Burner: Settlement Fails in the Treasury Market after 9/11." Federal Reserve Bank of New York Economic Policy Review, November 2002, 8(2), pp. 35-57.

Gerlach, Stefan and Schnabel, Gert. "The Taylor Rule and Interest Rates in the EMU Area." Economics Letters, May 2000, 67(2), pp. 165-71.

Greenspan, Alan, "Private-Sector Refinancing of the Large Hedge Fund, Long-Term Capital Management." Presented before the Committee on Banking and Financial Services, U.S. House of Representatives, October 1, 1998.

Hafer, W.R. and Haslag, Joseph H. "The FOMC in 1987: The Effects of a Falling Dollar and the Stock Market Collapse." Federal Reserve Bank of St. Louis Review, March/April 1988, 70(2), pp. 3-16.

Hirschkorn, Phil. "9/11 Memorial Design Contest Called Biggest Ever," May 30, 2003. www.CNN.com/2003/US/ Northeast/05/30/wtc.memorial/index.html.

Hobijn, Bart. "What Will Homeland Security Cost?” Federal Reserve Bank of New York Economic Policy Review, November 2002, 8(2), pp. 21-33.

Jensen, Gerald R.; Mercer, Jeffery M. and Johnson, Robert R. "Business Conditions, Monetary Policy and Expected Security Returns." Journal of Financial Economics, February 1996, 40(2), pp. 213-37.

Jorion, Philippe. "Risk Management Lessons from Long-Term Capital Management." European Financial Management, September 2000, 6(3), pp. 277-300.

Judd, John P. and Rudebusch, Glenn D. “Taylor's Rule and the Fed: 1970-1997." Federal Reserve Bank of San Francisco Economic Review, 1998, O(3), pp. 3-16.
Kogan, Richard. "War, Tax Cuts, and the Deficit." Report from the Center on Budget and Policy Priorities, July 8, 2003. www.cbpp.org/4-29-03bud.htm.

Lacker, Jeffrey M. "Payment System Disruptions and the Federal Reserve Following September 11, 2001.” Working Paper 2003-034A, Federal Reserve Bank of Richmond, December 23, 2003.

Levin, Andrew; Wieland, Volker and Williams, John C. "Robustness of Simple Monetary Policy Rules under Model Uncertainty," in John B. Taylor, ed., Monetary Policy Rules, National Bureau of Economics Research Conference Report Series. Chicago: University of Chicago Press, 1999, pp. 263-99.

McAndrews, James J. and Potter, Simon M. "Liquidity Effects of the Events of September 11, 2001." Federal Reserve Bank of New York Economic Policy Review, November 2002, 8(2), pp. 59-79.

Mishkin, Frederic S. "Financial Policies and the Prevention of Financial Crises in Emerging Market Countries." Working Paper 8087, National Bureau of Economic Research, January 2001.

Neely, Christopher J. "Technical Analysis and the Profitability of U.S. Foreign Exchange Intervention.” Federal Reserve Bank of St. Louis Review, July/August 1998, 80(4), pp. 3-17.

Neely, Christopher J. "An Introduction to Capital Controls." Federal Reserve Bank of St. Louis Review, November/ December 1999, 81(6), pp. 13-30.

Neely, Christopher J. "The Practice of Central Bank Intervention: Looking Under the Hood." Central Banking, November 2000, pp. 24-37.

Neely, Christopher J. “The Federal Reserve's Response to the Sept. 11 Attacks.” Federal Reserve Bank of St. Louis Regional Economist, January 2002, pp. 12-13.

Orphanides, Athanasios. "Monetary Policy Rules Based on Real-Time Data." American Economic Review, September 2001, 91(4), pp. 964-85.

Poole, William. "What Role for Asset Prices in U.S. Monetary Policy?" Speech presented at Bradley University, Peoria, IL, September 5, 2001.

Roberts, Paul Craig. "Monetary Policy Caused the Crash- 
Too Tight Already." The Wall Street Journal, October 22, 1987.

Rudebusch, Glenn D. and Svensson, Lars O.E. "Policy Rules for Inflation Targeting." Working Paper 6512, National Bureau of Economic Research, April 1998.

Saidenberg, Marc R. and Strahan Phillip E. "Are Banks Still Important for Financing Large Businesses?" Current Issues in Economics and Finance, August 1999, 5(12), pp. 1-6.

Santoni, J.G. "The October Crash: Some Evidence on the Cascade Theory." Federal Reserve Bank of St. Louis Review, May/June 1988, 70(3), pp. 18-33.

Sternlight, Peter D. and Krieger, Sandra. "Monetary Policy and Open Market Operations during 1987." Federal Reserve Bank of New York Quarterly Review, Spring 1988, 13(1), pp. 41-58.

Stewart, James B. and Hertzberg, Daniel. “Terrible Tuesday: How the Stock Market Almost Disintegrated a Day After the Crash—Credit Dried up for Brokers and Especially Specialists until Fed Came to Rescue-Most Perilous Day in 50 Years." The Wall Street Journal, November 20, 1987.

Stewart, James B. and Hertzberg, Daniel. "The Brady Report-Market Medicine: Brady Panel Proposals Underscore Worries '87 Crash Could Recur-Its Call for Radical Changes Is Spurred by Finding System Neared Collapse_Friday's 140 Point Nosedive." The Wall Street Journal, January 11, 1988.

Taylor, John B. "Discretion versus Policy Rules in Practice." Carnegie-Rochester Conference Series on Public Policy, December 1993, 39(0), pp. 195-214.

Taylor, John B. “The ECB and the Taylor Rule." International Economy, September/October 1998, 12(5), pp. 24-25, 58.

Thorbecke, Willem. "On Stock Market Returns and Monetary Policy.” Journal of Finance, June 1997, 52(2), pp. 635-54.

\section{Appendix}

Figure 1: The Bureau of Economic Analysis and Haver Analytics provide quarterly U.S. domestic investment data.

Figure 2: The Board of Governors and the Federal Reserve Bank of New York make available daily federal funds rate targets. The Federal Reserve Bank of Philadelphia maintains and publishes the real-time data on GDP and the GDP deflator. The Bureau of Economic Analysis supplies the most recent data on GDP and the GDP deflator.

Figures 3, 4, and 5: The New York Times and The Wall Street Journal provide daily data on the S\&P 500 index and the NYSE implied volatility, respectively. The Board of Governors of the Federal Reserve makes available data on the yields on 10-year U.S. government bonds, the trade-weighted value of the dollar, and U.S. official foreign exchange intervention. 